\title{
The type and frequency of interactions
} that occur between staff and children outside in Early Years Foundation Stage settings during a fixed playtime period when there are tricycles available

Article

Accepted Version

Bilton, H. (2012) The type and frequency of interactions that occur between staff and children outside in Early Years Foundation Stage settings during a fixed playtime period when there are tricycles available. European Early Childhood Education Research Journal, 20 (3). pp. 403-421. ISSN 17521807 doi: https://doi.org/10.1080/1350293X.2012.704763 Available at https://centaur.reading.ac.uk/25670/

It is advisable to refer to the publisher's version if you intend to cite from the work. See Guidance on citing.

To link to this article DOI: http://dx.doi.org/10.1080/1350293X.2012.704763

Publisher: Taylor and Francis

All outputs in CentAUR are protected by Intellectual Property Rights law, including copyright law. Copyright and IPR is retained by the creators or other copyright holders. Terms and conditions for use of this material are defined in the End User Agreement. 


\section{www.reading.ac.uk/centaur}

\section{CentAUR}

Central Archive at the University of Reading

Reading's research outputs online 
HELEN BILTON

PGCE PRIMARY PROGRAMME DIRECTOR

UNIVERSITY OF READING

BULMERSHE COURT

WOODLANDS AVENUE

EARLEY

RG6 1HY

01183785830

h.o.bilton@ reading.ac.uk

Title: The type and frequency of interactions that occur between staff and children outside in Early Years Foundation Stage settings during a fixed playtime period when there are tricycles available.

Keywords: outdoor play, interactions, talk, tricycles, outdoor environment, playtime 


\begin{abstract}
ABSTRACT: This study reports on an investigation into adult and child interactions observed in the outdoor play environment in four Local Authority early years foundation stage settings in England. In this instance the common two features across the settings were the presence of tricycles and a timetabled outdoor play period. In total, across the four schools, there were 204 children. The study aimed to gain an understanding of the nature of the dialogues between staff and children, that is, the types of exchange that occurred when either the child approached an adult or the adult approached a child. The most frequent type of utterance was also analysed. The study concludes that adults in these settings spoke more than children and the greatest type of utterance was that of the adult about domestic matters. When the child initiated the conversation there were more extended child utterances than domestic utterances. This may suggest that children wish to be involved in conversations of depth and meaning and that staff need to become aware of how to develop this conversational language with children.
\end{abstract}

RÉSUMÉ: Cette étude est un rapport d'enquête sur les interactions entre adultes et enfants observées dans les aires de jeux extérieures dans quatre établissements publics (écoles maternelles) en Angleterre. Dans ce cadre, les deux points communs entre ces établissements étaient la présence de tricycles et un créneau horaire de jeu à l'extérieur. Il y avait au total 204 enfants. L'étude avait pour objectif de comprendre la nature des dialogues entre le personnel et les enfants, c'est-à-dire le type d'échanges qui ont lieu soit quand un enfant approche un adulte ou quand un adulte approche un enfant. Le type de propos le plus fréquent a été également analysé. Cette étude conclut que, dans ce contexte, les adultes parlent plus que les enfants et que le type de propos le plus fréquent venait des adultes et était de nature pratique. Lorsqu'un enfant commençait une conversation, il y avait plus de paroles enfantines que de propos de nature pratique. Ceci suggère que les enfants souhaitent avoir des conversations profondes et 
significatives et que le personnel doit être formé pour savoir comment développer ce langage conversationnel avec eux.

ZUSAMMENFASSUNG: Diese Studie berichtet über eine Untersuchung über die Interaktionen von Erwachsenen und Kindern in ihrem ersten Jahrgang, d.h. im Alter von 4 bis 5 Jahren, die in der Umgebung vom Spielen im Freien in vier Schulen der örtlichen Schulbehörden in England beobachtet wurden. In diesem Fall waren die zwei gemeinsamen Merkmale in allen Situationen das Vorhandensein von Dreirädern und ein im Stundenplan vorgesehenen Zeitraum zum Spielen im Freien. In allen vier Schulen betraf diese Untersuchung insgesamt 204 Kinder. Das Ziel dieser Studie bestand darin, die Art der Dialoge zwischen den Lehrern und den Kindern besser zu verstehen, das heißt, welche Wortwechsel stattfanden, wenn entweder ein Kind einen Erwachsenen ansprach oder umgekehrt. Die am häufigsten vorgekommene Äußerungsart wurde auch analysiert. Die Studie kommt zum Schluss, dass Erwachsene öfter in dieser Umgebung sprachen als Kinder und die am meisten aufgetretene Äußerungsart von den Erwachsenen kam und mit häuslichen Angelegenheiten verbunden war. Wenn das Kind das Gespräch eröffnete, folgten mehr verlängerte Äußerungen als Äußerungen über häusliche Angelegenheiten. Dies könnte darauf hindeuten, dass Kinder wünschen, an ausführlichen und bedeutungsvollen Gesprächen beteiligt zu werden. Weiterhin muss es den Lehrern bewusst sein, wie man diese Unterhaltungssprache mit Kindern entwickelt.

RESUMEN: Este estudio es un informe de investigación sobre la interacción entre adultos y niños observado en patios de recreo al aire libre en cuatro escuelas públicas de primer año en Inglaterra. En este contexto, las características comunes entre estos establecimientos eran la presencia de triciclos y un periodo establecido de jugar al aire libre. Había un total de 240 niños. El estudio tenía como objetivo de entender la naturaleza de diálogos entre el personal y los niños, es decir el tipo de palabras que hay o cuando une niño aborda un adulto o cuando un adulto aborda un niño. El tipo de palabras más frecuente se analizó también. Este estudio concluye que en este contexto, los adultos hablan más que los niños y que el tipo de palabras más frecuente de los adultos es de naturaleza practica. Cuando un niño empezaba 
una conversación, había más palabras infantiles que de palabras de naturaleza practica. Éste insinúa que los niños prefieren conversaciones profundas y significativas y que el personal se debe estar capacitado a fin de saber como desarrollar este lenguaje con ello. 


\section{Introduction}

\section{Language Development}

Language acquisition is crucial to being successful. One of the baby and young child's overriding preoccupations is to communicate and through this early communication is the foundation for all literacy skills including helping a child to read (Bee and Boyd 2010, Bruner 1983, Evangelou, Sylva, Kyriaou, Wild and Glenny 2009, Goswami 2010, Snow 2006). This is a universal given and children across the world acquire language in similar ways through the construction of representations of the sounds heard (Hoff 2005). Children begin to learn language by hearing it and then saying it. The actual process of speaking and listening, that is conversing helps children to gain a strong vocabulary and children with a large oral vocabulary are likely to have few problems in learning to read (Snow 2006, Hart and Risley 1992). Dockrell, Stuart and King 2010 argue: 'Oral language development is central to a child's ability to access the curriculum and develop literacy skills' (1). Goswami (2001) asserts that children need to acquire a large vocabulary but also this links to phonological development. Learning the language is not simply about hearing it but needs to involve the process of conversation; exposure isn't enough children need to be involved with others (McKeown and Beck 2004) to construct meaning about the world around them (Wells 1987). Finally, the Face to face project, reviewed 81 pieces of research evidence to make recommendations about effective communication between parents/carers and their babies and young children. The most successful interactions for language development and acquisition were where both adult and child were both interested and engaged in the subject, with the child leading the conversation. (DfE 2010). 


\section{Language acquisition and educational settings}

When children goes to an educational setting this need for language development continues and children requires those more knowledgeable to support their understanding. More often than not the more knowledgeable will be an adult. Adults are central in helping in the process of learning, moving children forward in their understanding and to support and scaffold learning (Pollard 2008, Siraj-Blatchford, Sylva, Muttock, Gilden, and Bell, 2002, Vygotsky 1978). Therefore, how adults interact with children will impact on their learning and the Effective Provision of Pre-School Education (EPPE) Project has been reporting on this. This project is a large scale, longitudinal study in the United Kingdom focusing specifically on the effectiveness of early years education. This has been looking at the progress and development of 3,000 children in various types of pre-school education.

\section{Conversation}

One of the major findings from this study has established that children are helped to move forward in their learning when the adults are truly engaged with the children over time and through real conversations (Sylva, Melhuish, Sammons, Siraj-Blatchford, and Taggart, 2004). This is termed 'sustained shared thinking'. By its very nature, sustained shared thinking involves talking and listening as children try to make sense of what they are engaged in, using the adults as a resource to learn:

“More 'sustained shared thinking' was observed in settings where children made the most progress. 'Sustained shared thinking' occurs when two or more individuals 'work together' in an intellectual way to solve a problem, clarify a concept, evaluate an activity, extend a narrative etc. Both parties must contribute to the thinking and it must develop and extend the understanding' (Sylva et al 2004: 4). 
This study indicates that sustained shared thinking usually happens when children are working with one other person. It involves open ended questioning, and staff provide immediate and formative feedback with the adults modelling how to behave.

A study by Smith (1999) into 'shared attention episodes' on 200 under two year olds in child care centres in New Zealand found that some children did not actually have any interactions with staff and where there were no 'shared attention episodes' the scores on various assessments were noticeably lower than where children did experience such episodes. The author argues for 'the central importance of language and shared meaning and the richness of joint attention episodes as a context for learning' (Smith 1999: 85). Although this study is dealing with children younger than those in the Effective Provision of Pre-School Education Project (Sylva et al 2004) it is significant that both have concluded that when adults in educational settings do not involve themselves in deep and meaningful conversations with children, children suffer developmentally.

These studies indicate that conversation matters and the type of conversation particularly matters. 'Conversation is the most effective way for children to practice and refine their language skills including vocabulary' Evangelou, Sylva, Kyriaou, Wild and Glenny (2009: 28). This ensures children learn the language, learn how to manipulate that language to then develop understanding of the world and gain the ability to learn the skills of reading and writing. An English Government initiative, Every Child a Talker (DCSF 2009), was set up to ensure all children's entitlement to a rich oral environment. The centrality of the materials made available to practitioners is that there is a right way to encourage conversation and there is a wrong way. The right way means the adult has to make sure the child is central, so the conversation is about what they are doing, it is semantically contingent, so adults repeat what a child has said and has 
to be part of the daily life, not a set activity. However, conversation not only involves the use of vocabulary but also understanding of the etiquette of the process, including the skills of give and take. The giving part (talking) is about sharing information, ideas, thoughts, opinions, and the taking part (listening) of paying attention to the information, ideas, thoughts and opinions of others. To then respond appropriately to that information. Understanding this process is learned by being part of a rich oral environment. Zimmerma, Gilkerson, Richard, Christakis, Xu, and Gray, (2009) indicate from their research that adult-child conversations are strongly associated with healthy language development, all aspects of it.

\section{Conversation at home and in school}

In 1984 Tizard and Hughes published research which strongly asserted that the conversations of the children observed at home were much more effective than those observed at nursery school; the data related to four year olds girls. This was a highly significant piece of research. The conversations at home with their mothers were rich, varied and involved 'passages of intellectual search' (Tizard and Hughes, 1984: 9). Through these conversations the child looked for understanding by asking questions and then responding to the answer. However, the authors concluded that this type of conversation and learning was not happening in the educational setting of the nursery. The conversations in the nurseries were frequently subdued and 'restricted to answering questions' and 'taking part in minimal exchanges' (9) often about rather mundane issues. The research also indicated that the rich language environment of home did not involve teaching as we tend to view it; that of the teacher imparting knowledge. The children were not being deliberately taught but were involved in learning alongside their mothers as the daily life unfolded. This research concluded that a conversation was sustained and continued for a good period of time by the use of certain techniques which came naturally to the 
parents. Such techniques included: commenting on the other person's contribution; making a spontaneous and relevant comment and asking a question. The use of these techniques alongside an environment where the child was able to and felt comfortable to ask multiple questions ensured language development was strong.

The Tizard and Hughes (1984) study with its description of the interaction between adult and child as 'passages of intellectual search' and the Sylva et al (2004) research with its description of the most successful interaction between adult and child as 'sustained shared thinking', and the Smith (1999) study with its 'shared attention episodes' would seem to be describing the same style of interaction. Over three decades research has suggested that how we converse with children in educational settings has an impact on their language development. Indeed, Dudley-Marling and Searle's (1991) recommendation of using 'talk around the edges' would point to a similar style of interaction. The studies appear to be suggesting that there are significant features of quality interaction: children asking questions, the dialogue being about current interests or happenings, the conversations often being quite lengthy, the adult demonstrating genuine interest in the content of the conversation, the learning occurring without direct teaching and not involving the standard teacher/ child interrogatory question/answer dialogue.

\section{Conversations outside in the early years outdoor environment}

Since the establishment of nursery (early year/kindergarten) education in England in 1914 there has been a tradition (Pound 1987, Webb 1974), to provide both an indoor and outdoor environment. With the arrival of the Early Years Foundation Stage Framework in England (DCSF 2008) there is now a statutory obligation for settings to provide and utilise this outdoor space for teaching and learning every day. Being outside is seen as a social, physical and 
educational experience where teaching and learning should be happening (DCSF, 2008). The benefits to children of being and learning outside are considered to be varied. They include health enhancing both physical and mental benefits: (Clements- Croome et al 2008; Blakemore and Frith 2005; Eccles 2008; Gallahue and Ozmun 2005; Gill 2007), and cognitive and linguistic benefits: Bruce 2005; Edgington 2004; Isenberg and Quisenberry 2002; Moyles 1989; Rogers and Evans 2008; Tovey 2007). Schools are expected to set up the outside as they would inside with the same focus on teaching and learning as the indoors. (Cartwright, Scott, and Steven 2001; Bruce 2005; Edgington 2004; Garrick 2009; Ouvry 2003; Tovey 2007). In this context, conversation would be anticipated as is expected in any learning environment whether it be inside or outside.

Garrick 2009 looking at outdoor play in the early years argues: 'there is a need for adults to review the opportunities for adults to interact with children during play and to support episodes of scaffolding, including 'sustained shared thinking' outdoors"' (30). This would seem to be all the more pertinent for those who are English language learners (ELL) or their language development has been disadvantage as they can have a higher chance of literacy difficulties and academic failure (August \& Shanahan, 2006; Hart \& Risley, 1992; Kieffer, 2008). Pupils with poor oral language skills are also less likely to respond to reading interventions (Al Otaiba \& Fuchs, 2006). Therefore, oral language development is important for the whole language and understanding process whether children are outside or inside. But outside was chosen as there is an understanding that it is different to inside and children and adults can view it differently. Studies by Mackett, Brown, Gong, Kitazana and Paskins (2007) and Stephenson (2002) indicate children do behave differently outside. 


\section{The environment for teaching and learning}

Blenkin and Whitehead argue that 'the most neglected and misunderstood dimension of the planned curriculum is the creation of an environment or setting in which education is to take place' (1988: 35. See also Bruce 2005, McAuley and Jackson 1992, McLean 1991, Pollard 2008, and Whitebread 2000). In the same way Gibson (1979) talks about affordance: that is the quality of an object or environment that allows an individual to perform an action. Research from Kyttä (2002) and Niklasson and Sandberg 2010 demonstrate how the environment or object does have a bearing on the player. Teachers can take time to consider the curriculum but sometimes little or no time to consider the environment for learning; this can be the fate of the outdoor environment.

There can be a resistance from some practitioners to use this outdoor environment appropriately, viewing it as a time for their own break and adult chat, seeing it as more akin to a fifteen minute recreational break similar to the primary playtime recess when children are left to play and the adults in attendance are there to police and supervise, not interact. Conversation with children therefore can be restrictive. In this environment adults do not see their role as one of developing a rich language environment, but to supervise. There is often little for children to do and even if children are interested they do not have sufficient time to concentrate and persevere. This leads to some schools and settings providing a limited range of equipment, heavily reliant on the use of tricycles; with sometimes no other equipment available for children (Bilton 2004). Evidence from the researcher's own observations and discussions with early years teachers would suggest this space becomes one of 'survival of the fittest', a time and place where the 3-wheeler rules. The children on the tricycles may not communicate with any adults, tending to avoid them in case they are requested to get off the tricycles to let someone else have a turn. The only conversation will concern the removal of one child to be replaced by another child on 
the 3-wheeler (Bilton 2010). A small scale study by Maynard and Waters (2007) argues that the staff tended to use the outdoor area in rather limited ways and there was little evidence of sustained shared thinking or planned real experiences for children. As the title of their paper suggests, was learning outside a missed opportunity?

\section{Methodology}

It therefore seemed apposite to take a closer look at the conversations between adults and children in early years outdoor settings to establish the nature of those conversations. Given the interest in the affordance of the environment and the knowledge that this can impact on learning it was decided to take a closer look at those settings where there is a fixed time outside and where there are tricycles.

The research question to be answered in this study was: What is the nature/type and frequency of interactions that occur between staff and children outside in Early Years Foundation Stage settings during a fixed playtime period when there are tricycles available? If this is narrowed down further the questions to be answered were:

1. What is the nature of the interactions between adults and children?

2. What are the least and most prevalent types of interactions instigated by children when approaching an adult?

3. What are the least and most prevalent type of interactions instigated by adults when approaching a child?

4. When the interactions are further converged into four categories- child extended, child domestic, adult extended and adult domestic- what are the least and most prevalent types of interactions? 


\section{Sample and Participants}

Four Local Authority, state run infant schools in South East England with early years foundation stage classes/units attached to schools were asked to take part in the research. All the schools adhere to the English statutory framework: The Early Years Foundation Stage (DCSF 2008). In order to explore the research, settings were chosen that had a set play period outside and had tricycles available as standard. Accessibility to the University of Reading was a final deciding factor on choosing the settings, so they were close enough for the researcher to observe on a daily basis.

The children were all aged 3-5 years. In one setting there were 26 children aged between 3 and the term just before they turned 5, accessing their own garden. In another the children were aged between 4 and half and 5 and half. In total there were 51 children from two openplanned classrooms accessing one garden. In another, 60 children between 4 and 5 years of age, based in two separate classrooms, accessed one garden. In the last school, 67 3-5 year olds, based in 2 classes, accessed the one garden area. In total across the four schools there were 204 children, but on no occasion were all the children outside at once. The research was simply concerned with the types and regularity of the interactions, therefore the gender, age, length of time in school of the individual was not considered. Neither was the frequency and types of interactions of an individual child; the individual as such was irrelevant to the study. The maximum number of adults outside at any one time was four, but the majority of observations involved either one or two adults.

\section{Methods and procedures}

Each class was visited a total of 12 times for a 20 minute period over a three month period during the summer term 2010. This totalled 48 twenty-minute observations. The children 
and staff were observed and any interaction between the two noted and marked down in the appropriate type of interaction category, with a simple tick. Initially the research was only concerned with interactions instigated by children to adults but during the pilot visits staff suggested that the researchers needed to observe interactions instigated by staff as well. At the end of the twenty minutes the number of interactions in each category were tallied up and added to the total for that type.

Adults and children were observed and their interactions categorised using a demand schedule similar to that used by Dunne and Bennett (1990) looking at talking and learning in groups and adapted by Bilton (2004). Dunne and Bennett (1990) were interested in the demands that children made on staff and concerned to demonstrate that we need to set up classrooms so children are making demands on staff of a cognitive nature not a low level nature such as asking for a pair of scissors. This outdoor study was interested in not only the type of interaction but whether that interaction fell into a category described as domestic or extended. Domestic described those low level interactions, to do with giving a directive or responding to a basic request; by its very nature the questions were closed and not requiring high order thinking (Donaldson 1978). Extended described an interaction which was open and had the potential to develop into higher order thinking and therefore learning and involved the development of understanding about the shared subject under discussion.

The interactions instigated by children categorised as domestic or involving low level language were:

\begin{tabular}{|l|l|}
\hline C1 & Asking for a bike Eg: 'can I have....' \\
\hline C2 & $\begin{array}{l}\text { Requesting to go to the toilet/inside/to get a coat Eg: } \\
\text { 'Can I go to the...' }\end{array}$ \\
\hline C3 & Asking for help because hurt Eg: 'I've got hurt...' \\
\hline C4 & To mend something Eg: 'Can you mend this?' \\
\hline C5 & Sorting out a disagreement Eg: 'Jayne is being \\
\hline
\end{tabular}




\begin{tabular}{|l|l|}
\hline & horrible, wont let me...' \\
\hline C6 & $\begin{array}{l}\text { Finding a resource/return something Eg: 'Can I } \\
\text { have...?' 'Can I have my....back?' }\end{array}$ \\
\hline
\end{tabular}

Those involving the potential for extended language and thereby having the potential to be extended interactions were:

\begin{tabular}{|l|l|}
\hline C7 & Requesting to play- Eg: 'Will you play with me...?' \\
\hline C8 & Talking about a discovery- 'Look what I have found...' \\
\hline C9 & $\begin{array}{l}\text { Talking about something the child had } \\
\text { done/created/made - 'Look at this...' 'I am.... }\end{array}$ \\
\hline C10 & $\begin{array}{l}\text { Seeking information/clarification - Eg: 'Do you want us } \\
\text { to...?' }\end{array}$ \\
\hline
\end{tabular}

Those interactions instigated by adults categorised as domestic or involving low level language were:

\begin{tabular}{|c|c|}
\hline A2 & Asking what something was- Eg: a painting \\
\hline A3 & $\begin{array}{l}\text { Asking whether assistance was needed in } \\
\text { dressing/hanging painting/etc; }\end{array}$ \\
\hline A4 & $\begin{array}{l}\text { Requesting to stop something/to share- when } \\
\text { something was viewed as dangerous or unkind }\end{array}$ \\
\hline A5 & A welfare enquiry- 'are you alright?' \\
\hline A6 & $\begin{array}{l}\text { Requesting to do something-go inside/put an apron } \\
\text { on/to read to an adult; }\end{array}$ \\
\hline A7 & $\begin{array}{l}\text { Offering an observation- 'you are going fast', } \\
\text { 'there's a long queue'. }\end{array}$ \\
\hline A8 & Interactions between observers and children. \\
\hline
\end{tabular}

Those interactions instigated by adults categorised as involving the potential for extended language and thereby seen as extended interactions were:

\begin{tabular}{|l|l|}
\hline A1. & $\begin{array}{l}\text { Adults explicitly facilitating learning through } \\
\text { why/how/what questions; encouraging questions. }\end{array}$ \\
\hline
\end{tabular}

\section{Analysis}


The results were analysed by establishing the most prolific and least prolific types of interactions, those instigated by children and those instigated by adults. Therefore the results were looking to comparisons and proportions to then make tentative conclusions. These were further analysed by grouping into four categories, see above- child domestic ( $\mathrm{C} 1$ to $\mathrm{C} 6$ ), child extended (C7 to $\mathrm{C} 10)$, adult domestic (A2 to A8) or adult extended (A1). It was agreed that those interactions with the researchers (A8) be deemed to be domestic as the researchers were not normally part of the staff group, but these results were not used when the categories were converged into adult domestic and extended. Domestic describes those interactions of a more administrative and low level nature which are unlikely to extend and develop conversation and thinking. Extended describes those interactions which might extend and develop conversation and thinking. Sustained shared thinking, an extended interaction would include a conversation concerning an interest but would not include a request for a bike.

\section{Researchers}

The two researchers, previously early years teachers, now lecturers in education at the University of Reading agreed the categories of observations with the schools. After each visit any interactions which did not neatly fall into a category were discussed. Both researchers made observations at all four settings.

\section{Ethics}

The ethics of the research went through the appropriate University committee. Schools were asked to partake and an initial visit made to discuss the research and the ethical considerations. Parental permissions were sought. During the initial visit the interactions form was shared and amendments made on the suggestions of schools. 


\section{Results}

1. What is the nature of the interactions between adults and children?

The answer to this question was found during the actual process of formulating the research and through dialogue with the staff in the schools involved in the research. Through the discussions more types of interactions were suggested. The nature of the interactions are clearly varied and of the interactions observed we were able to categorise them under the 10 child instigated headings and the 8 adult instigated headings. Children and staff approach each other to seek clarification or information, to discuss, to request, to comment, to share. This was made more concise by describing the interactions as either extended or domestic. Extended being those interactions which could lead to deep conversations which can extend thought or those of a domestic nature which are not intended to develop language and thought as such but are purely practical in their nature. Even though the play outside was for a limited and set period of time each day, and there were tricycles available children and staff did interact and did converse and every category of conversation was used.

2. What are the least and most prevalent types of interactions instigated by children when approaching an adult?

\section{Insert Figure 1 here}

Figure 1 reveals the totals of each type of interactions (C1-C10) for each school. Each school being colour coded and abbreviated. Of the domestic interactions instigated by children the most prevalent was to sort out a disagreement, not always over a tricycle but mostly over the control or ownership of them as opposed to any other toy. The least prevalent child instigated interaction, under the domestic category was to ask for something to be mended. Of the extended category the least prevalent was that of children seeking information/clarification or asking an 
adult to play. The most prevalent extended interactions instigated by children was to discuss what they had done, made, or created or what they had discovered.

3. What are the least and most prevalent type of interactions instigated by adults when approaching a child?

Insert Figure 2 here

Of the domestic interactions instigated by adults the least prevalent were asking what something was, for example a picture and asking whether help was needed with dressing/hanging a painting or how to do something. Offering an observation was the most prevalent domestic interaction, for example 'you're going fast', 'that's a long queue', 'that's big a hole, 'there are a lot in there' (referring to the number of snails in a pot). This was particular prevalent in one school and this school also recorded the mean highest number of extended interactions. There were a significant number of interactions to demand that children stopped doing something whether it was deemed dangerous or unkind.

4. When the interactions are further converged into four categories- child extended, child domestic, adult extended and adult domestic- what are the least and most prevalent types of interactions?

Table 1 here

The number of utterances of each type are given in Table 1. A chi-square test was used to investigate the distribution of numbers of types of utterances (chi-square $(3)=343.25 \mathrm{p}<.001$ ). This revealed that there were more adult domestic utterances than any other type of utterance and that the adults spoke more than the children. The mean numbers of utterances in each 20 minute observation session are illustrated in Figure 3.

Figure 3 about here 
This indicates that there was more adult language than child language per session. However, there were more extended child utterances than domestic child utterances and indeed the mean number of child extended utterances was greater than the mean number of adult extended utterances. Figure 4 demonstrates that this was so across all schools; in all four schools the children instigated more child extended utterances than domestic. Whether the limited number of adult instigated interactions to encourage learning was due to the presence of bikes and the timetabled outdoor play period is difficult to judge and the researcher considers a comparative study where outdoor play is available at all times and there are no tricycles should help. Figure 4 about here

Finally Figure 5 shows the actual mean number of utterances in a 20 minute period. Adult domestic utterances are nearly double the number of child extended utterances.

Figure 5 here

\section{Discussion}

From this study of four settings it is apparent there are a good range of interactions between staff and children. Some of these interactions have to be somewhat domestic; demanding of little cognitive effort because staff may need for example to ask children to be safe, or put on an apron, or ascertain whether someone is all right. These are functional interactions and often very practical in their nature. Likewise children need to sometimes have practical conversations such as asking for help either because they are hurt or upset or because they cannot resolve a problem on their own. These types of interactions and utterances will occur naturally in any setting. In terms of developing language they may at best be ensuring a child can follow an instruction. In terms of social and emotional development they are ensuring children are acting safely in terms of themselves and others. These conversations could not be 
construed as sustained shared thinking nor passages of intellectual search as they were short in duration and did not involve open ended questions and were not about developing ideas and concepts.

Looking to the results for child initiated interactions the most prevalent domestic interactions instigated by children was to sort out a disagreement, not always over a tricycle but mostly over the control or ownership of them as opposed to any other toy. This seems a pity on two fronts. Firstly, children need to be taught how to successfully react with each other regarding equipment and secondly precious minutes tick away as child on child have a disagreement over ownership of a toy. This may also reveal that certain toys or equipment have a status attached to them which children hanker for and argue over. If this is happening in a setting it would be important to change practice to stop this happening. That the least prevalent child instigated interaction was to ask for something to be mended may be viewed as a good thing as children were not causing damage to equipment and toys or that equipment was robust enough to stand the day to day usage. Or it could indicate that children did not have the opportunity to create and make.

Of the extended child initiated category the least prevalent was that of children seeking information/clarification or asking an adult to play. This is an interesting discovery given the early years rhetoric is full of references to play and the importance of play to the young child, for example Bruce 2005, Moyles1989, Pelligrini 1991and 2005, Rogers and Evans 2008, Wood and Attfield 2005 and of course Vygotsky 1978. Was it that children did not feel able to draw adults to them to play, or was it that they did not want them to play? Or was it that the environment outside was not conducive to asking adults to play? Or could it be adult involvement in play outside is less significant to children than other children playing with them? However, the 
children were keen to discuss what they had done, made, or created or what they had discovered. And they wanted to do this sharing with an adult not another child. This may suggest that the shared interests as specified in Sylva et al 2004 or Tizard and Hughes 1984 may be the type of interaction that staff should concentrate their efforts on to achieve sustained conversations involving significant utterances from the child. A study by Waters and Maynard (2010) indicate that a third of child initiated interactions with adults involved features of the outdoor environment; children wanted to converse about the here and now of the environment and their interface with it.

Of the interactions instigated by adults the least prevalent were asking what something was, for example a picture and asking whether help was needed with dressing/hanging a painting and so on. This would suggest that the staff in the four settings did not feel a need for children to describe pictures and anticipated that children would ask for help when they needed it. Offering an observation was the most prevalent interaction, for example 'you're going fast', 'that's a long queue', 'that's big a hole, 'there are a lot in there' (referring to the number of snails in a pot). Children rarely responded verbally to these offerings, although they often did with a facial expression. Therefore, although these utterances had the potential to extend conversation they were rarely responded to. But interestingly the school that had the most observational comments also had the highest number of extended interactions, but the two were not necessarily linked. This may suggest we need to comment less on proceedings outside than we think or we need to decide what is gained by making these comments. There were a significant number of interactions to demand that children stopped doing something whether it was deemed dangerous or unkind. Although it is important for adults to put a reign on children's behaviour if it becomes too dangerous or unkind, if this type of interaction is too prevalent there may be issues within a 
setting. For example it could be the setting is too concerned with safety and giving children insufficient opportunities for risk taking. It could be that there is too much unkindness and real danger and this would need to be looked at closely to find the reasons. It could be children do not have enough quality activities to be involved with.

Figure 5 shows the mean number of utterances with 10 child extended utterances per 20 minutes and nearly 20 adult domestic utterances per 20 minutes. A child may attend an early years class for as little as two and half hours per day. In a class of 26 children with 2 staff then each child could expect less than 6 minutes of dedicated time from each adult. If this is raised to a full day of 5 hours (excluding the lunch break), then each child could expect 12 minutes of adult attention per day each. This isn't a huge amount of time and indicates that staff in schools need to use their time wisely. This small scale piece of research would indicate that early years practitioner could pay attention to the types of interactions and conversations they are having with children and ensure they are thinking about sustained shared thinking or passages of intellectual search when in dialogue with children. Observations made during this research but not part of the research indicated that conversations were short and often clipped (interactions being seconds long) and few interactions were sustained over a long period of time.

Where there was a common purpose or shared interest such as gardening there were longer and more sustained conversations. The implications for practice are that adults need to interact with children concerning common purposes more along the lines of Dudley-Marling and Searle (1991), Sylva et al 2004 or Tizard and Hughes (1984). Practitioners need to become more aware of the potential of these common purposes or shared interests, which differ to play and could be described as work (Rogers and Evans 2008). These are situations where staff and 
children come together often for a common good, such as gardening or creating. This may also benefit those cultures who do not see play as important in a school situation (McNaughton 2000).

However, it would seem this is something that may not come naturally to all staff and would require training. Justice and Pence (2004) argue that what staff do, needs to be based on scientific evidence with a focus on innovating new practices in real-world contexts. The EELs (Early Effective Learning) project (Pascal and Betram1997) clearly demonstrates that if you want improvement, then staff need training and over a sustained period. A study by Dockrell et al (2010) would concur with this suggestion. This research was aimed at children with poor language skills in preschool in England, through the use of a language intervention programme. The intervention was preceded with staff training and was found to 'differentially positively affected children's receptive language, expressive vocabulary and sentence repetition' (Dockrell et al 2010:12). The children's oral language in this study did improve with oral intervention by staff who had been trained in the process.

It could be argued that children don't need adults outside as they benefit from simply conversing with their peers or that they have sufficient sustained conversation inside. Cullen (1993), Mackett et al (2007) and Stephenson (2002) would suggest that children behave differently inside to outside and may not need adults to the same extent. 'Children do behave differently at a microscale' (Mackett et. al 2007:1). Peter Moss argues we need to listen to children's wants and desires, rather than impose on them without a dialogue. Moss describes children as 'social actors', (Moss and Petrie 2002) experts in their own future. It may not always be possible through conversation to glean what young children want but this small scale observational research seems to suggest children through their actions are indicating that they would like more adult-child interactions of an extended and cognitive nature. So rather than 
'doing to' children, we may need to do more of 'doing with' children to develop their oral language.

\section{Conclusion}

The question posed in this study was: What is the nature/type and frequency of interactions that occur between staff and children outside in Early Years Foundation Stage settings during a fixed playtime period when there are tricycles available?

This study is clearly limited given the small sample size. The actual size and shape of the garden areas was not taken into consideration, nor was the level of planning. These aspects could impact on the quality of interactions. But the researcher was at this stage simply interested in attempting to categorise types of interactions between adults and children, to see if the measurement tool was useful and to see if particularly interactions types did indeed occur more frequently than others. Adults and children in this small sample study wished to interact with each other and both parties approached the other, even though the play periods were of a set time and there were tricycles present. They conversed for a variety of reasons: to seek clarification or information, to discuss, to request, to comment, to share. The majority of interactions instigated by the adult were administrative and practical in their nature, to do with following an adults' request.

A high proportion of domestic interactions instigated by children were about disputes over tricycles, this is simply not a good use of time in an educational setting. The larger number of interactions instigated by children were about learning -discoveries and findings. This is interpreted as indicating that the children talked about more than domestic topics and they did this more than the adults did. The results may indicate that adults are in a controlling regulatory 
role rather than one which is designed to facilitate language development. This would suggest that adults in early years settings need to take an audit of the utterances and quality of conversations between adults and children to then consider more acutely the language potential of activities on offer outside. It may also indicate that adults need to consider or reconsider what their role is outside-to supervise or to support learning.

Children wanted to talk about things that were happening to them then-the snails they had found, the water seeping through the pot, the imaginary pot hole in the road, the thorns on the tree. This is the type of interaction discussed in the Tizard and Hughes (1984) study. Mothers alongside their child talking about anything and everything as the day unfolded. To develop language it may be that we need to be concentrating on sweeping the leaves, and planting the carrots with the children rather than setting up adult initiated paly situations; working rather than playing. The theorists in the literature review suggest that quality conversations which develop oracy and then lead to developing literacy include the following: children asking questions, the dialogue being about current interests or happenings, the conversations often being quite lengthy, the adult demonstrating genuine interest in the content of the conversation, the learning occurring without direct teaching and not involving the standard teacher/ child interrogatory question/answer dialogue. To be meaningful therefore interactions need to be the meeting of minds not ships passing in the night. These categories could be used to both audit what is happening in a setting whether in or out and also to train staff in understanding what an effective language rich environment consists of.

The finding which was not measured but noted was: how long the interactions between adult and child were. What was noted but not measured was that most conversations were remarkably short, seconds long and rarely more than minutes long. The findings within the 
literature review demonstrate a clear link between time and learning. Children do need conversations which are over a good period of time and do involve the batting back and forth of ideas, questions and suggestions. To study the length of the interactions using the same conversation categories would ascertain which types of interactions do encourage this type of quality conversation leading to the extended use of language and thought processes.

This study has enabled the researcher to simply begin the exploration of interactions outside between children and adults and to analyse the quality of those conversations where there were a fixed play period and where there were tricycles. The next piece of research would be to look at the interactions in what is described as a free flow outdoor environment where outside and in are available at the same time and where there are no tricycles available. In this way a comparison of the two types of educational approach can be made to see if environment/affordance does impact on children's use of language. In this way it can be seen whether the length of time available to be outside and the lack of toys which can create disputes does enable children and adults to have deep, prolonged and meaningful conversations. Other related research would then enable suggestions to be made as to how the adults could organise outside and then work within it to maximise language opportunities.

\section{Acknowledgments}

I would like to thank all the children and staff for participating in this study and for the University of Reading for funding the study. I am grateful to Professor Rhona Stainthorp and Dr. Suzanne Graham for their help.

\section{References}


Al Otaiba, S., \& Fuchs, D. (2006) Who are the young children for whom best practices in reading are ineffective? An experimental and longitudinal study. Journal of Learning Disabilities, 39(5), 414-43

August, D., \& Shanahan, T. (Eds.) (2006) Developing literacy in second language learners: Report of the national literacy panel on language minority children and youth. Mahwah, NJ: Erlbaum.

Bee, H. and Boyd, D. (2010) The Developing Child 12 $2^{\text {th }}$ Edn Boston: Pearson Education. Bilton, H. (2004) Playing Outside. Activities, Ideas and Inspiration for the Early Years. London: David Fulton Publishers.

Bilton, H. (2010) Outdoor Learning in the Early Years. Abingdon: Routledge.

Blakemore, S. J. and Frith, U. (2005) The Learning Brain. Lessons for Education. Oxford: Blackwell Publishing

Blenkin, G. M. and Whitehead, M. (1988) 'Creating a context for development', in Blenkin, G.M. and Kelly, A.V. (eds) Early Childhood Education. A Developmental Curriculum. London: Paul Chapman. 32-60.

Bruce, T. (2005) Early Childhood Education ( $3^{\text {rd }}$ edn). London: Hodder Arnold. Bruner, J. (1983) Child's Talk: Learning to Use Language. New York: Norton. Cartwright, P., Scott, K. and Stevens, J (2001) A place to learn: developing a stimulating learning environment. Lewisham: Lewisham Early Years Advice and Resource Network. Clements- Croome, D. J., Awbi, H.B., Bako-Biro, Zs., Kochhar, N. and Williams, M. (2008) Ventilation rates in schools. Building and Environment The International Journal of Building Science and Applications 43,3, 362-7. 
Cullen, J (1993) Preschool children's use and perceptions of outdoor play areas. Early Child Development and Care 89/1 45-56.

DfCSF Department for Children, Schools and Families (2008) May revised. The Early Years Foundation Stage. Nottingham: DfCSF Publications.

DfCSF Department for Children, Schools and Families (2009) Every Child a Talker: Guidance for Early Language Lead Practitioners (Second instalment). Nottingham: DfSCF Publications. DfE Department for Education (2010) Highlights from a literature review prepared for the Face to Face research project. London: National Literacy Trust.

Dockrell, J. E., Stuart, M. and King, D. (2010) Supporting early language skills for English language learners in inner city preschool provision. British Journal of Educational Psychology. Donaldson, M. (1978) Children's Minds. London: Croom Helm Ltd Dudley-Marling, C. and Searle, D. (1991). When students have time to talk: Creating contexts for learning language. Portsmouth, NH: Heinemann.

Dunne, E. and Bennett, N. (1990) Talking and Learning in Groups. London: Routledge. Eccles, R. (2008) General Common Cold Information http://www.cardiff.ac.uk/biosi/subsites/cold/commoncold.html (accessed 27.12.08) Edgington, M. (2004) The Foundation Teacher in Action. Teaching 3,4 and 5 year olds. London: Paul Chapman Publishing. Evangelou, M., Sylva, K., Kyriacou, M., Wild, M. and Glenny, G. (2009) Early Years Learning and Development Literature Review Research Report Number DCSF-RR176. London: Department for Children, Schools and Families.

Gallahue, D. L. and Ozmun,J.C. (2005) Understanding Motor Development: Infants, Children, Adolescents, Adults ( $6^{\text {th }}$ edn). New York: McGraw-Hill Companies. 
Gibson, J.J. (1979) The Ecological Approach to Visual Perception. Boston: Houghton Miffllin. Gill, T. (2007) No Fear. Growing up in a Risk Averse Society. London: Calouste Gulbenkain Foundation.

Garrick, R. (2009) Playing Outdoors in the Early Years (2 ${ }^{\text {nd }}$ edn) London: Continuum International Publishing Group

Goswami, U. (2001) Early phonological development and the acquisition of literacy. Handbook of Early Literacy Research. 111.

Goswami, U. (2010) The Wiley-Blackwell Handbook of Childhood Cognitive Development: 2nd Edition. Blackwell Handbooks of Developmental Psychology. Chichester: Wiley-Blackwell. Hart, B., \& Risley, T. (1992) American parenting of language-learning children: Persisting differences in family-child interactions observed in natural home environments. Developmental Psychology, 28, 1096-1105.

Hoff, E. (2005) Language development. Wadsworth: Thomson Learning

Isenberg, J. and Quisenberry, N. (2002) Play: Essential for All Children. A position paper of the Association for Childhood Education International. Available:

http://www.acei.org/playpaper.htm Accessed December 2007

Justice, L. M., \& Pence, K. (2004) 'Addressing the language and literacy needs of vulnerable children: Innovative strategies in the context of evidence-based practice'. Communication Disorders Quarterly, 25, 173-178.

Kieffer, M. J. (2008) Catching up or falling behind? Initial English proficiency, concentrated poverty and the reading growth of language minority learners in the United States. Journal of Educational Psychology, 100, 851-868. 
Kyttä, M. (2002) Affordance of children's environments in the context of cities, small towns, suburbs, and rural villages in Finland and Belarus. Journal of Environmental Psychology. 22: $109-23$.

Mackett, R., Brown, B., Gong. Y., Kitazawa, K. and Paskins, J. (2007) ‘Setting children free: children's independent movement in the local environment', UCL Working Papers Series. University College London Centre for Advanced Spatial Analysis. Paper 118-March: 1-13. Maynard, T. and Waters, J. (2007) 'Learning in the outdoor environment: a missed opportunity?' Early Years, 27,3, 255-65.

McAuley, H. and Jackson, P. (1992) Educating Young Children. A Structural Approach. London: David Fulton Publishers.

McKeown, M. G. \& Beck, I. L. (2004). Direct and Rich Vocabulary Instruction. In Baumann, J. F., \& Kame'enui, E. J. Vocabulary Instruction: Research to Practice. New York: Guilford Press. McLean, S.V. (1991) The Human Encounter: Teachers and Children Living Together in Preschools. London: Falmer Press.

McNaughton, G. (2000) Rethinking Gender in Early Childhood Education. London: Paul Chapman.

Moss, P. and Petrie, P. (2002) From Children's Services To Children's Spaces: Public Policy, Children and Childhood. London: Routledge Falmer.

Moyles, J. (1989) Just Playing? The Role and Status of Play in Early Childhood Education. Milton Keynes: Open University Press.

Niklasson, L. and Sandberg, A. (2010) Children and the Outdoor Environment. European Early Childhood Education Research Journal. 18, 4, 485-496. 
Ouvry, M. (2003) Exercising Muscles and Minds: Outdoor Play and the Early Years

Curriculum. London: The National Early Years Network.

Pascal, C. and Betram, T. (1997) Effective Early Learning: Case Studies in Improvement (Zero to Eight Series) London: Sage Publications Limited.

Pelligrini, A.D. (1991) Applied Child Study. New Jersey: Lawrence Erlbaum Associates.

Pelligrini, A.D (2005) Recess: Its Role in Education and Development. Mahwah NJ: Erlbaum.

Pollard, A. (2008) Reflective Teaching. London: Continuum International Publishing Group.

Pound, L. (1987) 'The nursery tradition'. Early Child Development and Care. 28, 79-88.

Rogers, S. and Evans, J. (2008) Inside Role-Play in Early Childhood Education. Researching

Young Children's Perspectives. Abingdon: Routledge.

Siraj-Blatchford,I., Sylva, K., Muttock, S., Gilden, R. and Bell, D. (2002) Researching Effective Pedagogy in the Early Years. DfES Research Report

356.www.dfes.gov.uk/research/data/uploadfiles/RR356.pdf (2002)

Snow, C.E. (2006) What Counts as Literacy in Early Childhood? In McCartney, K. and Phillips, D. (Eds) Blackwell Handbook of Early Childhood Development. Oxford: Blackwell Publishing Limited. 274-294.

Smith, A.B (1999) 'Quality Childcare and Joint Attention'. International Journal of Early Years Education 7,1: 85-98.

Stephenson, A. (2002) 'Opening up the outdoors: exploring the relationship between the indoor and outdoor environments of a centre', European Early Childhood Research Journal, 10,1, 2938. 
Sylva, K., Melhuish, E., Sammons, P., Siraj-Blatchford, I., \& Taggart. B. (2004) The Effective Provision of Pre-School Education (EPPE) Project: Findings from Pre-school to End of Key

Stage 1. Nottingham: DfES. Ref: SSU/FR/2004/01.

Tizard, B. and Hughes, M. (1984) Young Children Learning Talking and Thinking at Home and at School London: Fontana Paperbacks

Tovey, H. (2007) Playing Outdoors. Spaces, and Places, Risk and Challenge. Maidenhead: Open University Press.

Vygotsky, L. (1978) Mind in Society. Development of Higher Psychological Processes.

Cambridge MA: Harvard University Press.

Waters, J. and Maynard, T. (2010) 'What's so interesting outside? A study of child initiated interaction with teachers in the natural outdoor environment'. European Early Childhood Education Research Journal 18, 4: 473-483.

Webb, L. (1974) Purpose and Practice in Nursery Education. Oxford: Blackwell.

Wells, G. (1987) The Meaning Makers. Children Learning Language and using Language to Learn. London: Hodder and Stoughton.

Whitebread, D. (2000) The Psychology of Teaching and Learning in the Primary School. Abingdon: Routledge.

Wood, E. and Attfield, J. (1996) Play, Learning and the Early Childhood Education. London: Paul Chapman Publishing.

Zimmerman, F. J., Gilkerson, J., Richard, J. A., Christakis, D. A., Xu, D., Gray, S., et al. (2009). Teaching by listening: The importance of adult-child conversation to language development. Pediatrics, 129, 342-349. 
Figure 1: Mean number of child initiated interactions for each school. C1-C10 denotes the type of question, with C1-C6 being describes as domestic and C7-C10 being described as extended and therefore more likely to develop language

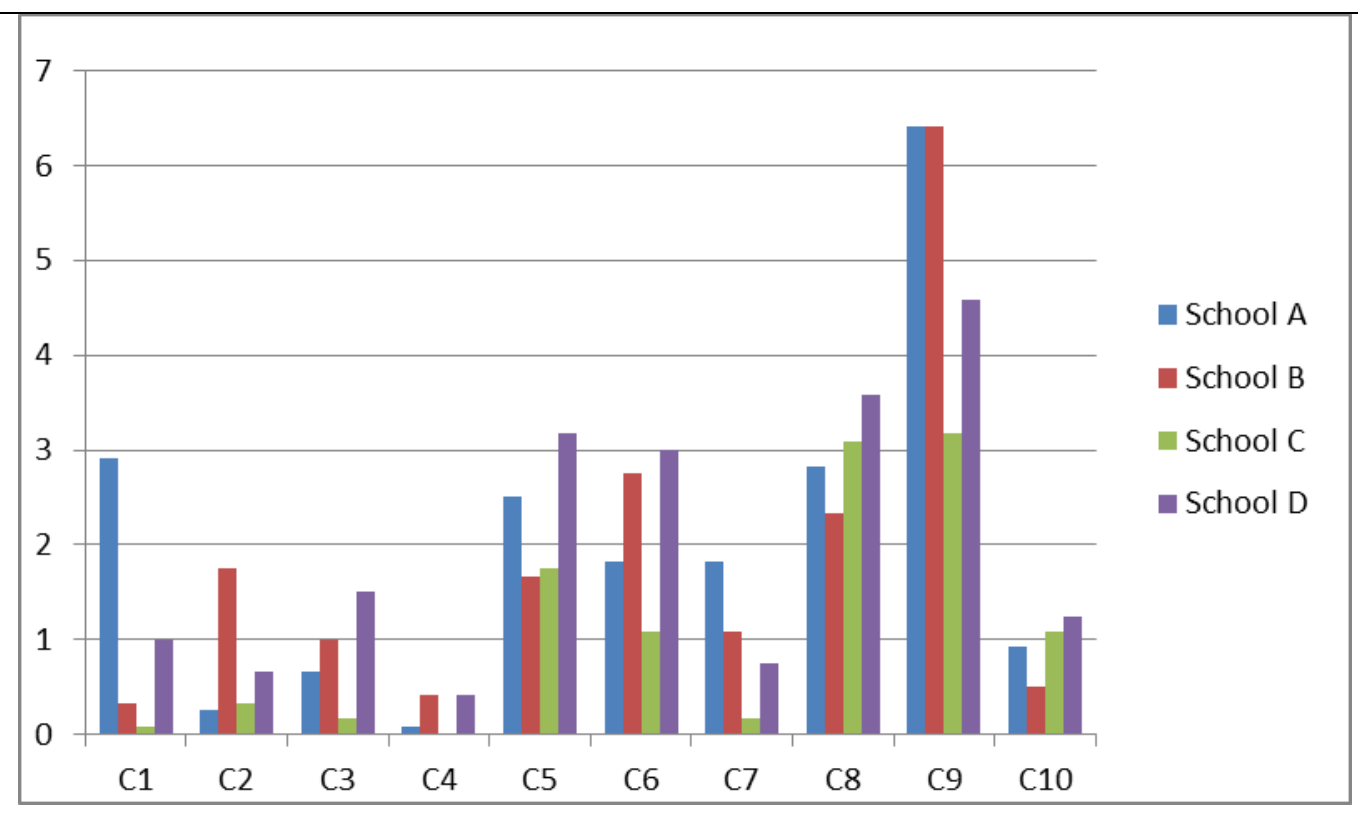

C1 asking for a bike;

C2 requesting to go to the toilet/inside/to get a coat;

C3 asking for help because hurt;

C4 to mend something;

C5 sorting-out a disagreement;

C6 finding a resource/return something.

C7 requesting to play;

C8 talking about a discovery;

C9 talking about something the child had done/created/made; 
C10 seeking information/clarification.

Figure 2: Mean number of adult initiated interactions for each school. A1-A8 denotes the type of question, with A2-A7 being describes as domestic and A1 being described as extended and therefore more likely to develop language. A8 were those interactions between the researchers and children, instigated by either party.

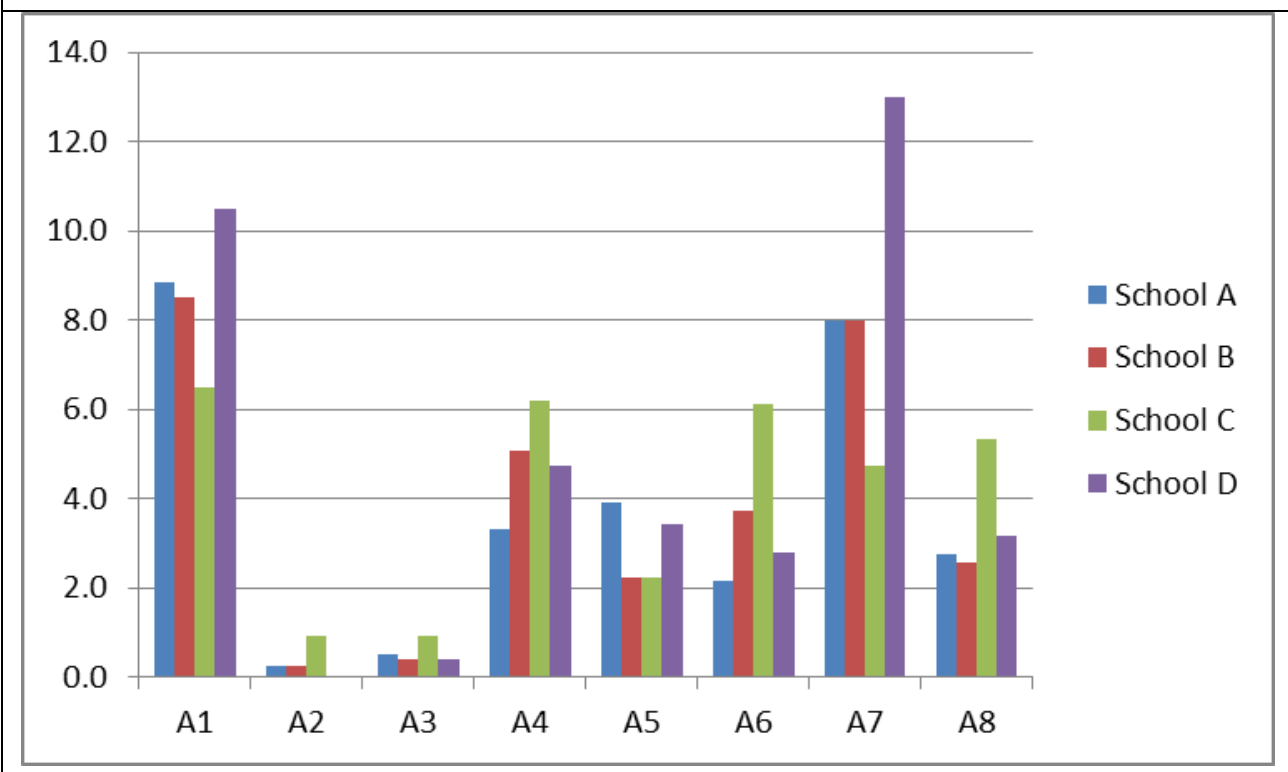

A1 adults explicitly facilitating learning through why/how/what questions; encouraging questions.

A2 asking what something;

A3 asking whether assistance was needed;

A4 requesting to stop something/to share- when something was viewed as dangerous or unkind;

A5 a welfare enquiry; 
A6 requesting to do something;

A7 offering an observation;

A8 children or the researchers interacting. 
Table 1: Total number of utterances recorded in the four schools over the 12 visits.

\begin{tabular}{lllll}
\hline & Adult Domestic & Adult Extended & Child Domestic & Child Extended \\
\hline Total Number of & 898 & 412 & 352 & 478 \\
utterances & & & & \\
\hline
\end{tabular}

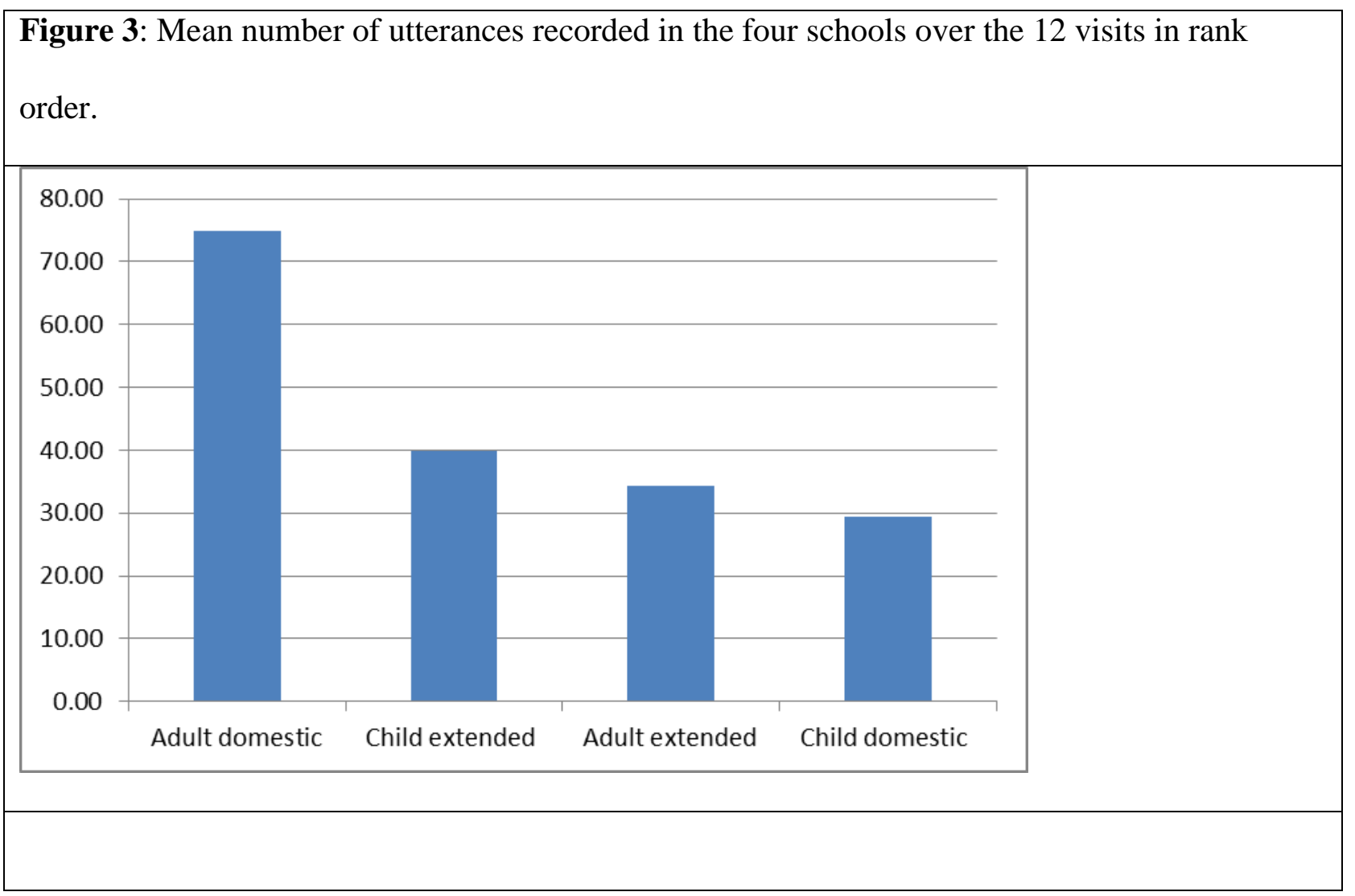




\begin{tabular}{l} 
Figure 4: Mean number of utterance types observed per minute in each school, demonstrating \\
quite similar results across all schools \\
\hline 1.20 \\
\hline 1.00 \\
\hline 0.80 \\
0.60
\end{tabular}


Figure 5: Mean number of utterance types observed across all schools and all visits per 20 minute observation

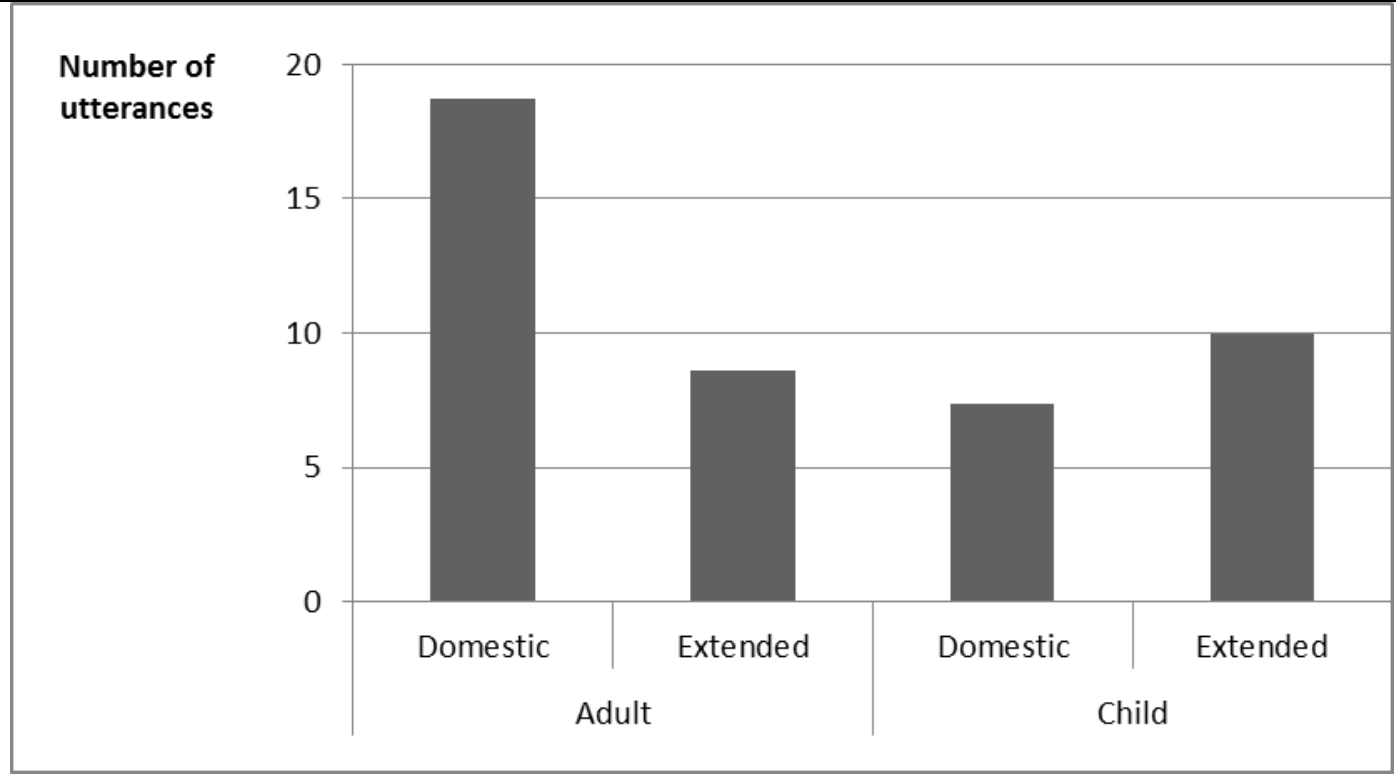

